\title{
ACUTE LYMPHOID LEUKEMIA (LLA): A PEDIATRIC CASE REPORT IN DIZYGOTIC TWINS
}

\section{Maria Larissa Correia De Lima1, Hudson Pimentel Costa ${ }^{2 *}$, Francisco Glauber Peixoto Ferreira ${ }^{2}$, Maria Imaculada Lourenço Meirú ${ }^{2}$, Matias Neto Alves Ferreira² ${ }^{2}$, Jéssica Bezerra Maciel $^{3}$, Lívia Paulia Dias Ribeiro ${ }^{2}$ and Danielle Rabelo Costa ${ }^{4}$}

${ }^{1}$ Biomedical clinical pathologist, Municipal Hospital São Sebastião, 63630-000, Pedra Branca-CE, Brazil; ${ }^{2}$ Academic Master's Degree in Sustainable Socio-biodiversity and Technologies - Institute of Engineering and Sustainable Development. University of International Integration of Afro-Brazilian Lusophony, 62785-000, Acarape-CE, Brazil; ${ }^{3}$ Academic Master in Natural Sciences - Center for Science and Technology. State University of Ceará, 60714-903, Fortaleza-CE, Brazil; “Biomedicine course - Catholic University Center of Quixadá, 63900257, Quixadá-CE, Brazil

\section{ARTICLE INFO}

\section{Article History:}

Received $19^{\text {th }}$ March, 2020

Received in revised form

$08^{\text {th }}$ April, 2020

Accepted $21^{\text {st }}$ May, 2020

Published online $29^{\text {th }}$ June, 2020

\section{Key Words:}

Neoplasia, Sisters, Hematopoietic system.

*Corresponding author:

Hudson Pimentel Costa

\begin{abstract}
Acute leukemias are considered neoplasias that reach the hematopoietic system, resulting in rapid clonal expansion and accelerated proliferation of blood cells. In this way, the cells lose their capacity for maturation and differentiation, accumulating young cells (blasts) and without function in the bone marrow. Acute lymphocytic leukemia (ALL) is a neoplasm that affects cells of the lymphoid lineage, but its prevalence occurs in B-cell precursors compared to T cells. It is common to occur in children between 1 and 5 years of age, comprising about $80 \%$ of the cases of all leukemias in this age group, but in adults, the probability of being present is lower. The present study aimed at the accomplishment of a case report on acute lymphoid leukemia in children, based on the comparison of risk factors in the family, and the evaluation of socioeconomic interference in the treatment, where, through an explanatory booklet, health professionals and the community about the major signs and symptoms of ALL in children. The research was submitted to the Ethics Committee of the Catholic University Center of Quixadá, through the Brazil Platform where it was analyzed and approved (01673218.2.0000.5046). In this study, we reported the case of two twin sisters who entered the Hospital São Sebastião de Pedra Branca, Ceará at different times, where one was admitted with fever and boulders, and another presenting only fever, after laboratory tests they were referred to a referral hospital in Fortaleza, Ceará, and were then diagnosed with acute lymphoid leukemia. Due to the poor prognosis of this pathology and a possible worsening of the patients' clinical status, they were referred for bone marrow transplantation. Fortunately, after the treatments performed, the twin had a positive evolution, no longer needing to undergo bone marrow transplantation.
\end{abstract}

Copyright (C) 2020, Maria Larissa Correia De Lima et al. This is an open access article distributed under the Creative Commons Attribution License, which permits unrestricted use, distribution, and reproduction in any medium, provided the original work is properly cited.

Citation: Maria Larissa Correia De Lima, Hudson Pimentel Costa, Francisco Glauber Peixoto Ferreira, et al. "acute lymphoid leukemia (lla): a pediatric case report in dizygotic twins", International Journal of Development Research, 10, (06), 36981-36985.

\section{INTRODUCTION}

Leukemia is a neoplasm that affects thousands of people worldwide, has characteristics and changes that specifically affect hematopoietic cells, to cause their rapid and unregulated development. In the initial phase of the disease, these cells will be present in the bone marrow, later on going to extra spinal areas (MOURA, 2014). Acute leukemias result from rapid clonal expansion and accelerated blood cell proliferation.
To lose the maturation and differentiation capacity, accumulating young cells (blasts) and without functions in the bone marrow. Blasts are first produced in the bone marrow, where they subsequently reach the peripheral blood and can enter hematopoietic organs such as the liver, spleen, and lymph nodes, and also reach non-hematopoietic organs such as the central nervous system, the skin, and the reproductive organs. The affected immature cells may come from the lymphoid or myeloid lines (KAVEH et al., 2017; CASADO et 
al., 2016). Among the various forms of this pathology, there is acute lymphoid leukemia (ALL), which is characterized by being a neoplasm that affects cells of the lymphoid lineage, with prevalence in the precursors of B lymphocytes, in comparison to $\mathrm{T}$ lymphocytes. occurrence in children, from 1 to 5 years old, comprising about $80 \%$ of all cases of leukemia in this age group. Children who develop ALL when diagnosed early have a $90 \%$ chance of total cure, demonstrating a good prognosis (NASCIMENTO et al., 2013; CRUZ, 2017). However, the big challenge is to make the diagnosis quickly and efficiently, because ALL symptoms are quite confused with other types of pathologies. Several factors contribute to the delay in diagnosis, among them are the lack of information and knowledge of parents, who often postpone the search for a diagnosis, as well as the inefficiency in the anamnesis process, the lack of trained professionals and the delay in service. public health system. These factors are extremely important, as the prognosis of these patients can be considered good, in the face of an early diagnosis, starting the treatment quickly and thus increasing the chances of cure (MATTOS, 2017). At the same time, the lifespan of children with ALL depends entirely on the efficiency and speed of diagnosis, as well as on the appropriate and specialized treatment for each type of patient, according to the ALL subtype and the stage of the disease. For this, information for a better understanding is necessary for a good understanding of the pathology, and thus help the most in the diagnosis, so that these children have more chances of cure and better quality of life. Although LLA is widely reported, information that helps health professionals is still lacking, especially in cities that do not offer specialist doctors and specialized exams at LLA (CRISTOVAM, 2014). In the meantime, the present study aimed to carry out a case report about ALL in children, based on the comparison of risk factors existing in the family, and the assessment of socioeconomic interference in the treatment.

\section{METHODOLOGY}

A research carried out was of the exploratory descriptive type with retrospective character and qualitative, transversal approach and source of the documentary base. A preceded institution went to the Municipal Hospital São Sebastião HMSS located in the city of Pedra Branca, Ceará, Brazil, between September to December 2018. For the research, the following criteria were taken into account: having the ALL, patients are dizygotic twins (2 years old), the socioeconomic influence to carry out the treatment and complications by the medical sector to obtain the diagnosis. Data collection took place through monthly meetings where clinical information was obtained through medical records, with emphasis on drug treatment and laboratory tests. Also, the patients' legal guardians were subjected to unstructured interviews, making it possible to report additional information for better data collection, exploring all necessary questions.

Data analysis and ethical aspects: The data were analyzed using the discourse analysis technique so that the information provided is recorded, classified and interpreted comprehensively, in which a sequence of steps around a (or more) guiding question is obeyed (ANDRADE, 2002). As Yin (2005) reports, a case study "is an empirical investigation that investigates a contemporary phenomenon within its real-life context, especially when the boundaries between the phenomenon and the context are not clearly defined". With this focus, the logic revolves around the set of statements presented and the objective and goals of the study in question, for this reason, the investigation involves the qualitative method (MINAYO, 2010), exercising two types of modalities: the instrumental one, because " it is developed to help in the knowledge or redefinition of the problem "and the collective, for having" the purpose of studying characteristics of a population "(GIL, 2008). The research was submitted to the Ethics Committee of the Centro Universitário Católica de Quixadá (UNICATÒLICA), with due approval by opinion 01673218.2.0000.5046. Respecting the precepts established by resolution 466/12 of the National Health Council, which regulates the guidelines and standards of research involving human beings.

\section{CASE REPORT}

Patient 1: M.A.A.M. patient, female, aged 1 year and 4 months, born in Pedra Branca - CE, coming from the city of Fortaleza - CE, was admitted to the Municipal Hospital São Sebastião, showing yellow spots on the nails of her hands, being immediately afterward diagnosed as nail fungus, the doctor then requested a complete blood count, the result of this examination showed all the vestments within the reference value, then the patient was medicated and discharged. Two months later, the patient was admitted to the São Sebastião Municipal Hospital again, showing purple spots on her body and constant fever, a blood count was requested, the biochemistry responsible for the examination, verified a large number of young lymphocytes, and the number of leukocytes. elevated, after dialogue with the doctor and analysis of exams by the same, the patient was transferred to Hospital Albert Sabin, Fortaleza-CE. On December 7, 2016, the patient had bruises on the upper and lower limbs and fever, then a new blood count was requested, which presented bicitopenia (decrease of two blood series) in the case of the patient in question, her bicitopenia was anemia and thrombocytopenia: platelets $\left(8,901 \mathrm{~mm}^{3}\right)$, erythrocytes $(2,078 \mathrm{~mm})$, hemoglobin $(5.6 \mathrm{~g} \mathrm{/} \mathrm{dl)} \mathrm{and} \mathrm{hematocrit}(19 \%)$ and leukocytosis $\left(52,000 \mathrm{~mm}^{3}\right)$, being then hospitalized on December 8, 2016. On December 9, 2016, a myelogram was performed that showed lymphoblastic B-cell leukemia, with $98 \%$ of bone marrow blasts, with a final diagnosis of high-risk Acute Lymphoblastic Leukemia. Chemotherapy treatment was started on December 9, 2016, with myelogram with 3\% blasts, markedly hypocellular bone marrow, and DRM 2.36\% (lumbar puncture: the absence of neoplastic cells). A new myelogram was then performed, which showed bone marrow apparently in cytological remission and less than $1 \%$ of the blast (lumbar puncture: the absence of neoplastic cells).

On January 3, 2017, he presented a positive culture for S. aureus, resistant to oxacillin and sensitive to vancomycin: blood cultures were performed on $02 / 01,01 / 05$, and $01 / 11$ performed at the tip of the catheter and showed contamination by Candida albicans. He underwent antibiotic treatment, improving his condition, a new blood culture was performed on January 18, 2017, with a negative result. During hospitalization, she presented with febrile neutropenia, with abdominal distension and abdominal wall edema. On January 11, 2017, ultrasound was performed, obtaining a normal abdominal result, normal amylase and lipase. The last febrile peak was on January 13, 2017, with improvement in the condition the patient was discharged, this being on January 23, 2017, with a return review for January 26, 2017, to perform a 
new blood count and biochemical tests. A summary of the therapy used can be seen in Figure 1.

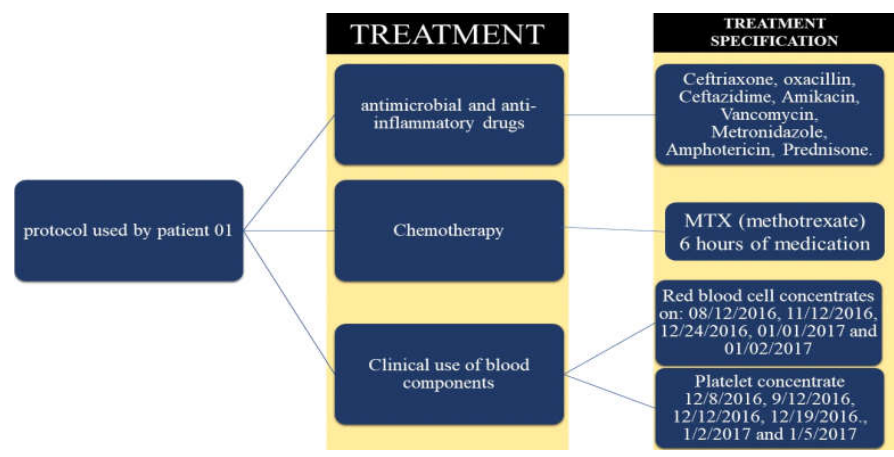

Figure 1. flowchart summarizing the treatment protocol used on the patient 1

Motor rehabilitation through physical therapy and Total Parental Nutrition (TPN) were also part of the treatment. Some surgical procedures were part of the treatment, such as the puncture of the central venous access in the right subclavian vein on December 21, 2016, which was removed on January 14, 2017.

Patient 2: M.C.A.M. patient, aged 1 year and 8 months, born in Pedra Branca - CE, from the city of Fortaleza - CE, was admitted to the Municipal Hospital São Sebastião with a fever, the doctor on duty aware of the conditions of his twin sister, the forwarded to Albert Sabin Hospital, where a blood count was performed on February 6, 2017, with the patient showing bruises on the upper and lower limbs, and fever, the blood count showed bicitopenia, with anemia and thrombocytopenia: platelets $\left(341,900 \mathrm{~mm}^{3}\right)$, red blood cells $\left(3,394 \mathrm{~mm}^{3}\right)$, hemoglobin $(9.8 \mathrm{~g} / \mathrm{dl})$, hematocrit $(29.1 \%)$ and leukocytosis $\left(28,000 \mathrm{~mm}^{3}\right)$. A myelogram was performed with a $57 \%$ blast count, closing the diagnosis of low-risk L1 Acute Lymphoid Leukemia. She was then referred to the ICU where she stayed for 6 days, evolved with Tiflite (inflammation of the cecum) and pneumonia, being treated with antibiotic prophylaxis (ATB), meropenem and vancomycin evolving with stability. On March 3, 2017, an abdominal ultrasound was performed showing a large amount of intra-abdominal fluid, his TGO exams with results well above the reference value being $120 \mathrm{u} /$ $\mathrm{L}$ and TGP $284 \mathrm{u} / \mathrm{L}$, previously they were performed and presented normal values. Discharged on March 15, 2017. Therapeutics used is described in the flowchart illustrated in Figure 2. Patient 2, as well as her sister, also used physical therapy and TPN.

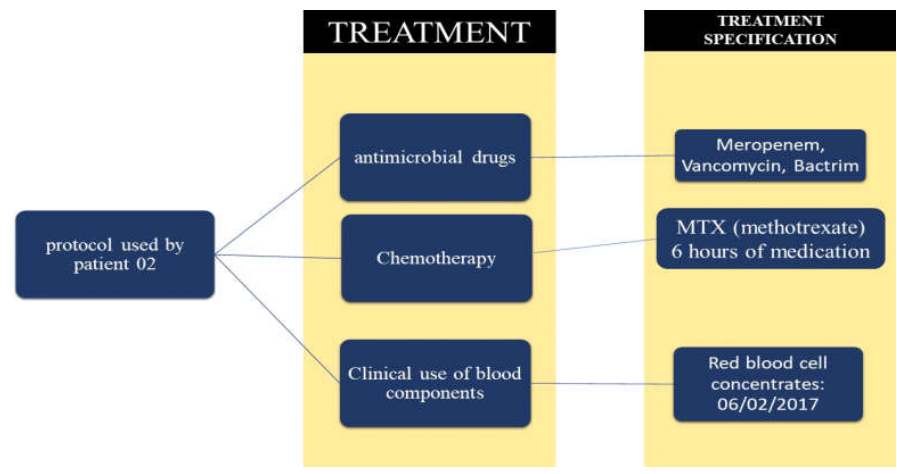

Figure 2. flowchart summarizing the treatment protocol used on the patient 2
The Sisters showed a good response to chemotherapy, also using drugs to prevent nausea. There were 2 hours of hydration and 6 hours of medication in an interval of 21 days. Both were placed on a list for bone marrow transplantation. On June 5, 2018, a donor compatible with the patients was found, but the preoperative exams showed that the spinal cord of both was healthy, free of blasts, without the need for transplantation. Patients will be monitored periodically to assess the risk of recurrence.

\section{DISCUSSION}

The reports described corresponding to the diagnostic criteria of the British American Franco group with the presence of a blast equal to or greater than $30 \%$ in the bone marrow, with elevated leukocytosis, low amount of platelets, along with myelogram, demonstrating the number of blasts in the $\mathrm{MO}$ in addition to classifying in acute L1 lymphoid leukemia of precursor B cells. Laboratory data of the complete blood count, myelogram, and clinical presentations collaborate for a more accurate diagnosis as corroborated by Molinari (2017). The finding in the myelogram of patient 01 reached $98 \%$ blast in the OM, with leukocyte parameters of around $47,000 \mathrm{~mm}^{3}$, diagnosed with ALL at 1 year and 6 months of age, in which it fits in the high-risk group according to the protocol (GBTLI99), which classifies the patient according to their bone marrow blast count, peripheral blood leukocyte count and the age at which the diagnosis was made. However, patient 02 presented a finding in the OM of $57 \%$ of blasts, her leukocyte count was $28,000 \mathrm{~mm}^{3}$, and her diagnosis was established at 1 year and 8 months of age, two months after her sister's diagnosis, but it fits in the low-risk group established by Rocha (2012). The treatment of the twins is different because even though they also have ALL, the sisters belong to different groups according to the Brazilian Childhood Leukemia Treatment Group (GBTLI-99), which separates patients into two groups: high risk and low risk if differentiating according to the criteria already mentioned, with this information the treatments of the patients are elaborated and which drugs will be used, the dose and days that should be administered as explana Casado (2016).

Patients 01 and 02 presented abdominal distension, due to the accumulation of fluid in the intra-abdominal region, one of the side effects that chemotherapy can cause. Chemotherapy aims to cause the death of leukemic cells, but chemotherapy is not only specific for altered cells, but it also affects cells that renew quickly, as is the case of cells of the digestive system and skin (RUSCHEL, 2016). Patient 02 had a TGO result of $42.0 \mathrm{u} / \mathrm{L}$ and TGP $242 \mathrm{u} / \mathrm{L}$. These results show liver changes, possibly originating from chemotherapeutic drugs that were metabolized in the liver, showing the overload that the liver suffered during treatment, plus a side effect, as chemotherapists have hepatotoxicity (MATTOS, 2017). For Ávila (2013) these results occur from the 3rd cycle of chemotherapy sessions, it is important to note that even with this change, the values of TGO and TGP can remain within the reference value, in most treatment. The chemotherapy of patient 01 , since it was more prolonged, there was a need to implant a venous catheter, constituted of silicone or polyurethane of single lumen, or multiple, classified as semi or implantable, used for the administration of the chemotherapy approached by Júnior et al ., (2010). However, there are some complications in its implantation, handling, and maintenance of this equipment with the occurrence of frequent infections 
caused by pathogenic microorganisms that can aggravate the general condition of patients. In the case of patient 01 , there was no apparent sign of infection by the catheter, but she presented fever and chills, then a blood culture was performed at the tip of the catheter, which was positive for Cândida formota. According to Danski (2017) fungi are responsible for $10-30 \%$ of all infections that occur in catheters. The fact that the patient is immunosuppressed due to chemotherapy makes her more susceptible to infections. During the treatment, both patients had the Hand Foot-to-Mouth Syndrome, which is caused by the highly contagious Coxsackie virus, common in children from 1 to 5 years of age, causing fever, blisters on the hands, feet, and mouth, and maybe acquired from food contaminated with the virus, possibly due to the depletion of patients' immunity (CRISTOVAM, 2014). In terms of risk factors, such as alcoholism, smoking, contact with ionizing radiation, age of the mother, and family history of hematopóieticas diseases, there is no relation of such factors on the appearance or aggravation of the pathology, in the patients of the study. However, socioeconomic factors can influence the application of effective treatment for patients with neoplasms who require intense pharmacological treatment, however, the sisters received assistance for the treatment of the city hall of the city in which they reside (MAIA, 2014; LAKN, 2017). Patient 01, had a low platelet count, this fact is manifested when blood cell production is disrupted by changes in OM affecting the morphology, quantity, and function of all cells in the hematopoietic system. Platelet concentrate administration was required. Both patients had the number of red blood cells well below the reference value, also resulting in a drop in hemoglobin, thus presenting normocytic and normochromic anemia, requiring the administration of red blood cell concentrates as stated by Campregher (2017).

ALL is easily confused with a bacterial or fungal infection, anemia, and other types of neoplasms. This shows the great importance of a differential diagnosis, which guarantees the most accurate conclusion. The first symptoms that arise, the doctor may be suspicious of any common infection in children, so it is necessary to request tests. The blood count will indicate the first necessary parameters, the high leukocyte count can indicate an infection and the low amount of hemoglobin indicate anemia as explained by Moreira (2018). Other parameters are analyzed, such as the presence of young cells, which have ALL. This can cause the doctor to rule out infections and anemias. Evidencing the importance of requesting more specific tests, such as myelogram, where an $\mathrm{OM}$ puncture is performed and the percentage of blasts is verified, this test is confirmatory for leukemia. But it is not the last test requested, it is essential to know what type of leukemia that patient has so that the treatment is as specific and effective as possible, thus performing a cytochemical examination, showing the type of blood cell that cancer has affected. Immunophenotyping identifies cell subtype (DANTAS, 2015).

\section{Conclusion}

Based on the results described above, it was possible to diagnose ALL. Due to the poor prognosis of this pathology and a possible worsening of the patients' clinical condition, they were referred for bone marrow transplantation. The assistance granted by the city hall in the city where the patients live was of great value for the treatment, since, even though the treatment was provided by the Brazilian Health System, travel costs were incurred since the city of the patients did not undergo pharmacotherapy proper. After the treatments performed, the twins' condition evolved positively, and it is no longer necessary to undergo bone marrow transplantation. The presentation and explanation of the case allowed highlighting the clinical and laboratory criteria, and the therapeutic alternatives recommended for patients with Acute Lymphoid Leukemia, demonstrating the importance of research in this category for the enrichment of science. In this way, the folder will serve as an information tool for health professionals and the community, assisting in the knowledge and perception of the main signs and symptoms of ALL, as well as contributing to the stages of diagnosis and prognosis.

\section{ACKNOWLEDGEMENT}

The authors would like to thank Instituto Nacional de TecnologiasAnalíticasAvançadas - INCTAA (CNPq, Process $\left.\mathrm{n}^{\circ} 465768 / 2014-8\right)$.

\section{REFERENCES}

ANDRADE, Maria Margarida de. Como preparar trabalhos para cursos de pós-graduação: noções práticas. 5. ed. São Paulo: Atlas, 2002.

ÁVILAR, Fernanda Fatima et al. Perfil Hematológico e Bioquímico Sérico de Pacientes submetidos a Quimioterapia Antineoplásica. Revista de Enfermagem e Atenção em Saúde. Uberaba, v.2, n.2 p. 32-45, fer 2013.

BRASIL. Ministério da Saúde. Secretaria de Atenção à Saúde. Departamento de Atenção Básica.

CAMPREGHER, Paulo Vidal et al. Tratamento bem-sucedido de leucemia mieloide aguda recorrente após transplante com duplicação interna em tandem FLT3 usando combinação de indução por quimioterapia, infusão de linfócitos de doador, soferanib e azacitidina. Relato de três casos. Revista Einsten. São Paulo, v. 15, n.3, 8- 19, jan 2017.

CASADO, Luiz Felipe et al. Economic evaluation of obinutuzumab in combination withchlorambucil in firstline treatment of patients with chronic lymphocytic leukemia in Spain, Clinico Economics and Outcomes Researc, Espanha, v. 8, p. 475-484, 21 de set. 2016.

CRISTOVAM, Marcos Antonio da Silva. Sindrome Mão Boca e Pé: Relato de Caso. Revista Medicina. Curitiba, v. 16, n.1, p 42 -45, jan-mar 2014.

CRUZ, Pamella da Silva et al. Qualidade de vida dos pacientes com leucemia mieloide crônica em uso de imatinibe. Revista de Enfermagem. Recife, v. 11, n. 6, p. 2423-2431, jun. 2017.

DANSKI Mitzy Tannia Reichembach et al. Complicações Infecciosas Assosiadas ao Cateter Venoso Central Totalmente Implatavel. Revista de Enfermagem. Recife, v 11, n 12, p 5809-5813, dez 2017.

DANTAS, Giselly Karitta Santana el al. Diagnóstico Diferencial Da Leucemia Linfóide Aguda Em Pacientes Infanto-Juvenis. Revista da Universidade Vale do Rio Verde, Três Corações, v. 13, n. 2, p. 3-18, 2015.

GIL, Antônio Carlos. Métodos e técnicas de pesquisa social. 6 ed. São Paulo: Atlas, 2008.

JUNIOR, Milton Alves das Neves. Infecções em cateteres venosos centrais de longa.São Paulo,2010.

KAVER, Kamaran et al. Comobination therapeutics of nilatinib and radiation in lymphoblastic leucemia as na 
effective method agasinst drug-resistance. PLOS Computational Biology. California, v. 13, n.7, p. 1-14, Jul de 2017.

LAKN, Dani et al. Avaliação da sobrevida de crianças com leucemia linfocítica aguda tratadas com o protocolo Berlim-Frankfurt-Munique, Jornal de Pediatria. São Paulo, Jul de 2017, v. 79, n. 2, p. 149-158.

MAIA, Raquel da Rocha Paiva. Infecções na infância, características maternas e leucemia linfocítica aguda em crianças. 2014. 168f. Tese (Pós-Graduação em Saúde Pública para a obtenção do título de Doutor em Ciências). Universidade de São Paulo, São Paulo, 2014.

MATTOS, Camille Xavier. Necessidades De Saúde De Familiares De Crianças Com Leucemia: Conversas E Metáforas No Itinerário De Cuidados. 2017. $191 \mathrm{f}$. Dissertação (Pós- Graduação). Universidade Federal do Rio de Janeiro, Rio de Janeiro, 2017.

MINAYO, Maria Cecília de Souza (org.). Pesquisa social: teoria, método e criatividade. 29. ed. Petrópolis, RJ: Vozes, 2010. (Coleção temas sociais).

MOLINARI, Poliana Cristina Carmona et al. Avaliação Dos Efeitos Ósseos Tardios E Composição Corporal De Crianças E Adolescentes Tratados De Leucemia Linfoide Aguda Segundo Protocolos Brasileiros, Revista Paulista de Pediatria, São Paulo, v. 35, n. 1, p.78-85, jan de 2017.
MOREIRA, L. A.; BATISTA, S. C.; SILVA, J. B.M. Diagnóstico de Leucemia Linfoide Aguda: um Revisão. Revista Saúde em Foco. São Paulo, v.10, n. 1, p 279-288, mar. 2018.

MOURA, Rolim. Leucemia - Sociedade em risco. 19f. Artigo (Graduação em Farmácia). Faculdade São Paulo, São Paulo, 2014.

NASCIMENT, Danille Moreira et al. Experiência em cuidados paliativos à criança portadora de leucemia: a visão dos profissionai, Ciência \& Saúde Coletiva, Minas gerais, v. 18, n. 9, p. 2721-2728, jun de 2013.

ROCHA, Bianca Corrêa. Leucemia Linfóide Aguda: Relato De Um Caso E Revisão De Literatura. 2012. 18f. Artigo (Residência Medica). Hospital do Servidor Público Municipal, São Paulo, 2012.

RUSCHEL, Luíza et al. Aumento Lateral Bilirenal com manifestação Leucemia Linfóide Aguda. Revista AMRIGS. Porto Alegre, v. 60, n.4, p 279-399, out. dez. 2016.

YIN, Robert K. Estudo de caso: planejamento e método. Porto Alegre: Bookman, 2005. 